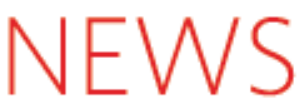

\title{
Bird flu spreads among Java's pigs
}

\section{TOKYO}

Concerns over the presence of a dangerous strain of avian flu virus in Indonesia's pigs are growing, as government tests confirm the existence of infection. In some areas, the $\mathrm{H} 5 \mathrm{~N} 1$ virus could be infecting up to half of the pig population, without causing any signs of disease.

The initial discovery was made earlier this year by an independent researcher working outside national and international surveillance systems. Chairul Nidom, a virologist at Airlangga University's tropical-disease centre in Surabaya, Java, found the H5N1 virus in five of ten pigs tested from Banten in western Java.

The presence of the virus in pigs is a particular worry because the animals can harbour both bird and human flu viruses, and act as a 'mixing vessel' for the emergence of a strain of avian flu that can easily infect humans. There are now signs that the virus could be spreading unchecked through the pig population.

Nidom says that the pigs he tested showed no signs of illness, and the only reason he tested them was that they were kept near a chicken farm that was struck by avian flu last year. Nature has discovered that a government survey has since found similar results in the same region.

The virus was not found in 150 pigs tested from outside the area. Although the government says it has stepped up the surveillance of pigs in its seven satellite laboratories, it may fail to spot any spread of the virus because resources are short. "It's a big country," says Tri Satya Putri Naipospos, director of animal health at Indonesia's agriculture ministry. ${ }^{\text {"If }}$ you want to commit to eradicating a disease, you need more money."

Nidom is also frustrated by a lack of resources. He says he has samples from another
90 pigs in Banten, but cannot afford to test them or to expand his survey to other areas.

Some health officials in Asia fear the presence of avian flu in pigs even more than in chickens or ducks. ${ }^{\alpha}$ I think pigs pose a much greater threat of spreading the disease to humans than poultry," says Nidom.

The virus was found in pigs in China in

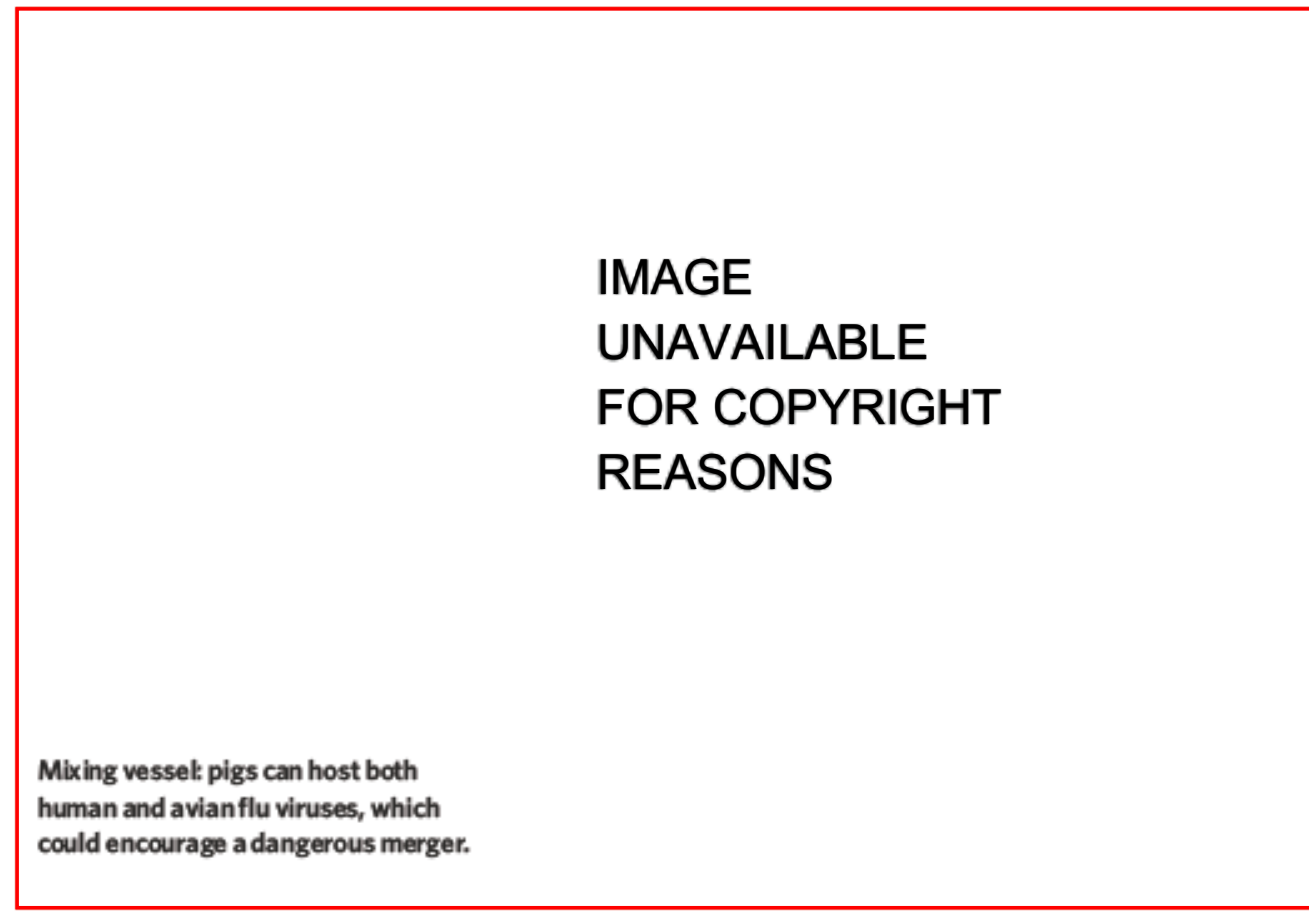

\section{Ecologist's tenure hailed as triumph for academic freedom}

\section{SAN DIEGO}

In a closely watched test case for academic freedom, the University of California, Berkeley, has granted tenure to an outspoken ecologist.

Ignacio Chapela, who once led faculty objections to Berkeley's research pact with Novartis, was told on 17 May that his fiveyear quest for tenure had finally succeeded. "It is just amazing," Chapela told Nature.

"This is like a new start in academia."

In the United States and beyond, the Chapela tenure fight has symbolized the conflict between academics' freedom to challenge policies, and the relationship between public universities and industry. The case has taken on special significance in recent years as professors at other US universities have come under attack for their views, with leading politicians calling for reduced tenure protections.

The Berkeley campus has become known for its battles over free speech, and as word about the tenure approval spread, there was elation among supporters of the Mexican researcher. "This has restored my faith in the institution," says Wayne Getz, an environmental scientist who championed Chapela's cause.

In 1998, the College of Natural Resources at Berkeley accepted $\$ 25$ million from the Switzerland-based Novartis (now Syngenta). Shortly afterwards, Chapela raised questions about the impact of the five-year deal on research and teaching. The issue bitterly divided the campus into those who supported and opposed the deal. Chapela's quest for tenure was complicated by a controversial article he wrote for Nature about the flow of transgenes into wild maize varieties in Mexico (I. H. Chapela and D. Quist Nature 414,541-543; 2001) - parts of which were later called into question.

Faculty committees supported Chapela's application for tenure, but in 2003 it was denied by the chancellor at the time, Robert Berdahl, who acted on advice from the final review committee. Chapela appealed to the faculty senate, alleging that the process had been corrupted by pro-industry faculty members. An academic senate inquiry last year decided that there were irregularities, setting the stage for another review by a newly constituted, high-level committee. 


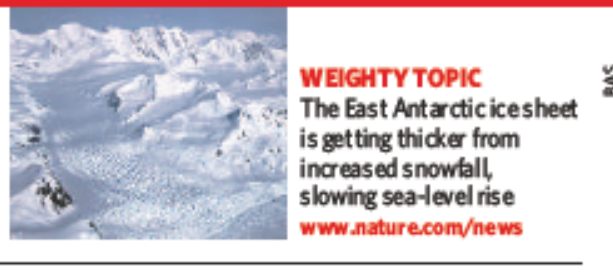

2001 and in 2003 (see Nature 430, 955; 2004). The country stepped up its surveillance, and two surveys in 2004 found that all 8,457 samples tested were free of $\mathrm{H} 5 \mathrm{~N} 1$.

Nidom's discovery of $\mathrm{H} 5 \mathrm{~N} 1$ in pigs is a wake-up call for the Indonesian government. He says that when he first alerted the government to his findings in February, there was no reaction. "I don't know why they are so passive," he says. Nidom took his findings to a local newspaper, the Jakarta-based Kompas, which ran the story on 9 April. The news spread to international media earlier this month.

The government responded to the media attention by carrying out its own survey, and found H5N1 in three out of eight pigs it tested in Banten, Naipospos told Nature. Like those tested by Nidom, the pigs showed no outward signs of disease.

Despite this worrying result, communication has faltered between Indonesia and the international organizations charged with monitoring animal health, such as the United Nations' Food and Agriculture Organization (FAO) and the World Organisation for Animal Health (OIE). When interviewed by Nature last week, the OIE's regional representative for the Asia-Pacific region still referred to the presence of $\mathrm{H} 5 \mathrm{~N} 1$ in pigs as "a rumour".

The FAO and OIE cannot act until they have received official government reports, says Carolyn Benigno, animal-health officer at the FAO's regional headquarters in Bangkok. She hadn't heard of Nidom's work until Nature contacted her last week. However, Naipospos complains that although she is preparing an official report for the FAO, she cannot fast-

\section{FLU BULLETINS}

The past week has seen the release of worrying data on the risk of a human pandemic, alongside almost daily news of further cases of avian flu.

VIRUS EVOLVING On 18 May, the World Health Organization (WHO) confirmed that the epidemiology of human outbreaks of avian flu in northern Vietnam this year is different from that elsewhere, and could be consistent with human-to-human transmission. There are not enough data to make a direct link, but the $\mathrm{WHO}$ has also found genetic changes in strains from northern Vietnam that could be consistent with the virus evolving to be more infectious.

Sequencing data of isolates from several countries also suggest more rapid evolution. Last year, all $\mathrm{H} 5 \mathrm{~N} 1$ samples were broadly similar. But this year, viruses from northern Vietnam and Thailand form a separate cluster from those isolated from southern Vietnam and Cambodia.

TAMIFLU RESISTANCE FOUND H5N1 isolated from a patient in northern Vietnam was found to have partial resistance to oseltamivir (Tamiflu), the antiviral drug that countries are rushing to stockpile (see page 407). Tamiflu is the drug of choice for treating $\mathrm{H} 5 \mathrm{~N} 1$. More monitoring of resistance is urgently needed, the WHO warned in a report on 18 May.

CASES INCREASE On 19 May, the $W H O$ reported a rise in cases in the current outbreak of human $\mathrm{H} 5 \mathrm{~N} 1$ infections - up from 89 cases and 52 deaths on 4 May to 97 cases and 53 deaths, in Vietnam, Thailand and Cambodia. Last weekend, the Vietnamese media announced three further cases, one of whom has died.

\section{VIRUS REACHES}

MIGRATORY BIRDS On

21 May, China announced that $\mathrm{H} 5 \mathrm{~N} 1$ was responsible for the deaths of dozens of migratory bar-headed geese in the western province of Qinghai. China has sealed off areas around Qinghailake, which is a migratory stop for hundreds of thousands of birds, and has sent 3 million doses of poultry vaccine to the region.

\section{CONFUSION ININDONESIA} Out of 79 Indonesian poultry workers tested for $\mathrm{H} 5 \mathrm{NI}$, one sample has been confirmed as positive. As no symptoms were reported, the government had hoped to check another sample, but hasn't been able to find the man concerned. Declan Butler track it because the FAO and the OIE do not classify the case as an emergency. ${ }^{\alpha}$ This is not an outbreak, it's a finding," she says, because the pigs are not ill or dying. As Nature went to press, the Indonesian government was preparing to send a report on the matter to the OIE.

Nidom says he would like to expand his pro- ject, and to sample pigs from eastern Java. But he is not counting on being given the resources to do so. This is his second run-in with the government - in 2003 he caused a stir by releasing data showing that mass deaths of chickens at the time were caused by H5N1. David Cyranoski

\section{这 \\ IMAGE UNAVAILABLE FOR COPYRIGHT REASONS}

Last month, that committee advised Robert Birgeneau, the current chancellor, to grant tenure, which he did last week. Birgeneau was unavailable for comment, but university spokesman George Strait insists the tenure process was normal, if unusually protracted. "This shows the process works," he says. Chapela, now ranked as associate professor, has a slightly different view. "To me, it shows the system doesn't work, unless you fight," he says.

Chapela plans to reopen his laboratory, which was shut down in 2002 when the ongoing tenure battle affected his ability to secure grants. But he is also assessing his legal options. In March, he filed a lawsuit in a state court against Berkeley, alleging discrimination, retaliation and fraud in his tenure review, which the university denies. Some of his advocates are urging him to continue the fight for compensation.

"This is the first step. The true measure of the university's commitment to academic freedom will be its willingness to fix a system rife with problems," says David Quist, Chapela's most recent doctoral student. Chapela's anti-industry campaigns continue. He and his supporters spent every night last week cycling round the construction site of a bioengineering centre on the Berkeley campus, to draw attention to planned industrial partnerships.

Rex Dalton 